\title{
Copper slag from different dumps in the Atacama Region used in mortars as partial replacement of cement
}

\author{
Osvaldo Pavez ${ }^{1,2}$, Amin Nazer ${ }^{3}$, Oscar Rivera ${ }^{4}$, \\ Macarena Salinas ${ }^{1}$, Bárbara Araya ${ }^{1}$
}

\author{
${ }^{1}$ Department of Metallurgical Engineering, University of Atacama, Atacama, Copiapó, Chile. \\ ${ }^{2}$ CRIDESAT, Atacama Regional Center for Research and Sustainable Development, University of Atacama, Atacama, \\ Copiapó ,Chile. \\ e-mail: osvaldo.pavez@uda.cl,macarena.salinas@alumnos.uda.cl,barbara.araya@alumnos.uda.cl \\ ${ }^{3}$ Department of Construction, Technological Faculty, University of Atacama, Atacama, Copiapó, Chile. \\ e-mail: amin.nazer@uda.cl \\ ${ }^{4}$ Centre for Pyrometallurgy, Department of Materials Science and Metallurgical Engineering, University of Pretoria, \\ Pretoria, Gauteng, South Africa. \\ e-mail: oscar.rivera.likao@gmail.com
}

\section{ABSTRACT}

The use of copper slag as a partial substitute for cement in mortar preparation was studied. Copper slag samples were collected from three dumps in the Atacama Region (Northern Chile). Mortars of 40x40x160 $\mathrm{mm}$ (width, height, length) and curing times of 7, 28 and 90 days were used in mechanical testing. Tests were performed with $0 \%$ (control mortar), 5, 10, 15 and 20\% copper slag as partial replacement of cement. The results of mechanical tests showed a gradual increase in compressive and flexural strength at 7, 28 and 90 days in mortars containing copper slag when compared with the control mortar. The major differences between the control and copper slag mortars are evident after 7 days, which indicates that the presence of slag in the blends has a retardant effect on the hardening process. On the other hand, at 90 days, compressive and flexural strength was very similar for both control mortar and mortars containing copper slag. Optimal compressive and flexural strength values are achieved with $5 \%$ of cement substitution by copper slag. The study concludes that the use of copper slag in mortars presents a viable alternative for partial cement replacement, and also contributes to mitigate adverse environmental effects of copper mining.

Keywords: Copper slag, compressive strength, flexural strength, mortars.

\section{INTRODUCTION}

Copper slag (CS) is a massive metallurgical waste, and it is recognized as an industrial passive. It is obtained from the transformation of copper ore concentrates into metallic copper in the smelters. Its chemical composition is rich in iron, silicon and aluminum oxides. Slags are deposited in landfills that occupy large areas of land.

The main environmental impacts derived from slag disposition are soil usage and visual contamination of landscape. On the other hand, under certain climatic conditions, leaching may occur depending on the solution characteristics, affecting the original composition and crystalline structure of solid slag (DEMETRIO et al. [1]).

The Atacama Region in Northern Chile is one of the leading copper producer regions in Chile. Historically, it has been a pillar of the economy, and today constitutes one of the most essential copper producing areas in Chile. There are two contemporary copper smelters in operation: Hernan Videla Lira and Potrerillos, and there is evidence of ancient smelters dating from the XVIII century (NAZER et al. [2]).

Globally, slag production in the copper industry is approximately 24.6 Mton, of which 3.0 Mton is attributable to Chilean producers (GORAI et al. [3]; VALENZUELA [4]). There is thus a need to implement 
technologies to mitigate environmental impacts of these residues produced in copper pyrometallurgy. SHI $e t$ al. [5] indicated that the use of CS provides environmental and economic benefits for all related industries, particularly in areas where a considerable amount of CS is generated. In this context, the potential for the use of copper slags from deposits in the Atacama region in the construction industry presents an interesting research topic.

In the construction industry, the use of CS as partial replacement of ordinary Portland cement (PC) has been investigated. POOVIZHI AND KATHIRVEL [6] evaluated concrete mixes of the M25 grade for compressive strength, flexural strength and split tensile strength. Cement was replaced with CS by four proportions $(5 \%, 10 \%, 15 \%$ and $20 \%)$. These researchers indicated that the addition up to $15 \%$ of CS as cement yielded comparable strength with that of the control mix. ZAIN et al. [7] reported that while the addition of CS to cement increased initial and final setting times, the strength of CS mortar was generally lower than control mortar, an optimal strength was achieved using a 5\% replacement of cement by CS. ORIZOLA [8] studied the behavior of hydraulic cement mortars in response to the addition of CS as a replacement of PC, reporting that the addition of $25 \%$ CS increased the mechanical strength of both ordinary and high-strength cement, while $40 \%$ CS increased the mechanical strength of ordinary cement. NAIDU et al. [9] evaluated the effectiveness of CS by replacing cement in the range of $0 \%$ (no CS), 5\%, 10\%, 15\% and $20 \%$.

The best results were obtained with 15\% of CS. MOURA et al. [10] reported the potential use of CS as a supplementary cementing material for concrete production, indicating that concrete batches comprising 20\% CS demonstrated enhanced mechanical properties and durability. BRINDHA AND NAGAN [11] presented the results of an experimental study about corrosion and durability tests on concrete containing CS as partial replacement of cement. For this research work, M20 grade concrete was used, and tests were conducted for various proportions of CS replacement cement of 0 to $20 \%$ in concrete. These researchers indicated that since CS concrete exhibits good durability characteristics, it can be used as an alternate in cement as a raw material for making blended cement. SÁNCHEZ DE ROJAS et al. [12] showed that the substitution of 30\% cement by CS reduces flexural and compressive strength in a similar way to fly ash.

These decreases were reported to abate after 28 days, but strength always remained lower than control mortar. They reported that pozzolanic activity of CS is similar to fly ash and lower than silica fume. A study regarding mortars comprising mixes of cement and CS found that compressive strength is lower in the early stages, but that results were reversed at 28 days, concluding that CS results in a delaying effect in the hardening process (ALP et al. [13]). NAJIMI et al. [14] replaced cement with CS at ratios ranging from 0 to $15 \%$, immersing samples in $\mathrm{Na}_{2} \mathrm{SO}_{4}$ solution for 120 days. Concrete with CS showed greater response to sulfate attack, and under normal conditions, compressive strength decreased with increases in CS content. SINGH et al. [15] reported that CS can be used as a supplementary cement replacement in concrete, with an optimal CS/cement ratio of 10\%. BHARATH et al. [16] studied of the effect of CS has as a supplementary cementing material in concrete, engineering properties of concrete containing $0 \%, 10 \%, 15 \%, 20 \%$ and $30 \%$ of CS when magnetized water is used for mixing the concrete.

These researchers reported that the compressive, split tensile and flexural strength were found the maximum in concrete with $85 \%$ of cement $+15 \%$ of CS with magnetized water. JUN-WEI [17] studied the effect of using CS as a replacement of cement on the properties of concrete. The results pointed out that there is a potential for the use of CS as a supplementary cementing material to concrete production. This researcher reported that the CS has a micro pozzolanic effect and that the concrete batches with CS addition present greater mechanical and durability performance. NAZER et al. [2] studied the pozzolanic behavior of CS from Chilean smelters on PC mortars using 25\% CS; they also studied the pozzolanic reactivity of alkaliactivated mortars cured at 20 and $65^{\circ} \mathrm{C}$. Results showed that CS has cementing properties.

Considering that the use of CS from dumps by the construction industry could contribute to improving local environmental conditions, the main objective of this study was to evaluate the mechanical behavior of mortars, using CS from three dumps located in the Atacama region in partial replacement of cement.

\section{MATERIALS AND METHODS}

\subsection{Materials}

The CS samples were collected in the following dumps located in the Atacama Region: Nantoco (NT-CS), Canto del Agua (CA-CS) and Puquios (PU-CS). Samples were processed by jaw and cone crusher (5 and 3 
$\mathrm{mm}$ setting, respectively) as well as in a disk mill, to comply with the required particle size distribution standard.

High Strength Portland Cement (HSPC) was used with NT-CS, CA-CS, and PU-CS, according to the NCh 148 Of 68 standard. Sand river and drinking water were used in all tests. Sand particle size distribution was adjusted according to NCh 163 Of 79 and NCh 165 Of 2009 standards.

\subsection{Methods}

For the chemical analysis of cement and NT-CS, CA-CS and PU-CS, oxidized compounds were determined by X-ray Fluorescence using a PANalytical Axios mAX - XRF spectrometer with lithium tetraborate fusion method.

The particle size distribution (PSD) of cement, NT-CS, CA-CS and PU-CS was assessed using a Malvern Mastersizer 2000 particle size analyzer. Complementary characteristics as size, morphology, and surface of the CS particles were evaluated by scanning electron microscopy (SEM) and in a Zeiss EVO MA 10 scanning electron microscope.

Design parameters for compressive and flexural tests under the NCh 158 Of 67 standard are presented in Table 1. Both compressive and flexural strength tests were done in duplicate. Specimens of 40x40x160 $\mathrm{mm}$ (width, height, length), with curing times of 7, 28 and 90 days, were used in mechanical testing. The curing process consisted of submerging samples in water and lime-saturated water, according to NCh 2261 Of 1996 standard. The tests were performed using 0\% (control mortar), and 5, 10, 15 and 20\% NT-CS, CACS and PU-CS content as a partial replacement of HSPC.

Table 1: Formulation of NT-CS, CA-CS and PU-CS mortars.

\begin{tabular}{c|c|c|c|c|c}
\hline CS CONTENT (wt \%) & CURING TIME (days) & CEMENT (g) & CS (g) & Sand $\mathbf{( g )}$ & Water (g) \\
\hline 0 & $7,28,90$ & 450.0 & 0.0 & 1350 & 240 \\
\hline 5 & $7,28,90$ & 427.5 & 22.5 & 1350 & 240 \\
\hline 10 & $7,28,90$ & 405.0 & 45.0 & 1350 & 240 \\
\hline 15 & $7,28,90$ & 382.5 & 67.5 & 1350 & 240 \\
\hline 20 & $7,28,90$ & 360.0 & 90.0 & 1350 & 240 \\
\hline
\end{tabular}

\section{RESULTS}

\subsection{Characterization of NT-CS, CA-CS, PU-CS and cement}

Table 2 shows the results of chemical analysis of NT-CS, CA-CS and PU-CS. High concentrations of $\mathrm{SiO}_{2}$, $\mathrm{Fe}_{2} \mathrm{O}_{3}, \mathrm{CaO}$ and $\mathrm{Al}_{2} \mathrm{O}_{3}$ are detected. Table 3 presents the results of chemical analysis of the cement, showing high concentrations of $\mathrm{CaO}$ and $\mathrm{SiO}_{2}$.

Table 2: Chemical analysis (wt \%) of NT-CS, CA-CS and PU-CS.

\begin{tabular}{c|c|c|c}
\hline COMPOUND & NANTOCO CS (wt \%) & CANTO DEL AGUA CS (wt \%) & PUQUIOS CS (wt \%) \\
\hline $\mathrm{Al}_{2} \mathrm{O}_{3}$ & 10.61 & 4.99 & 8.38 \\
\hline $\mathrm{SiO}_{2}$ & 49.88 & 32.68 & 41.11 \\
\hline $\mathrm{TiO}_{2}$ & 0.49 & 0.25 & 0.33 \\
\hline $\mathrm{Fe}_{2} \mathrm{O}_{3}$ & 19.21 & 47.15 & 27.75 \\
\hline $\mathrm{CaO}$ & 9.76 & 11.10 & 17.74 \\
\hline $\mathrm{MgO}$ & 1.92 & 0.93 & 2.23 \\
\hline $\mathrm{SO}_{3}$ & 0.15 & 0.40 & 0.33 \\
\hline $\mathrm{Na}_{2} \mathrm{O}$ & 1.78 & 0.34 & 0.69 \\
\hline $\mathrm{K}_{2} \mathrm{O}$ & 2.17 & 1.21 & 0.59 \\
\hline $\mathrm{MnO}$ & 0.74 & 0.16 & 0.43 \\
\hline $\mathrm{P}_{2} \mathrm{O}_{5}$ & 0.24 & 0.29 & 0.15 \\
\hline $\mathrm{SrO}$ & 0.06 & 0.01 & 0.02 \\
\hline $\mathrm{BaO}$ & 1.41 & 0.07 & 0.01 \\
\hline
\end{tabular}


Table 3: Chemical analysis of HSPC (wt\%).

\begin{tabular}{c|c|c|c|c|c|c|c|c|c|c|c}
\hline COMPOUND & $\mathrm{Al}_{2} \mathrm{O}_{3}$ & $\mathrm{SiO}_{2}$ & $\mathrm{TiO}_{2}$ & $\mathrm{Fe}_{2} \mathrm{O}_{3}$ & $\mathrm{CaO}$ & $\mathrm{MgO}$ & $\mathrm{SO}_{3}$ & $\mathrm{Na}_{2} \mathrm{O}$ & $\mathrm{K}_{2} \mathrm{O}$ & $\mathrm{MnO}$ & $\mathrm{P}_{2} \mathrm{O}_{5}$ \\
\hline wt \% & 5.12 & 19.40 & 0.28 & 3.32 & 64.99 & 0.86 & 3.00 & 0.23 & 0.22 & 0.08 & 0.06 \\
\hline
\end{tabular}

The particle size distribution curve of NT-CS, CA-CS and PU-CS used as partial replacement of HSPC is shown in Figure 1, with 90\% of particles smaller than 24.81 (NT-CS), 25.78 (CA-CS) and 27.39 (PU-CS) $\mu \mathrm{m}$. Figure 2 shows cement particle size distribution, with $90 \%$ of particles smaller than $48.69 \mu \mathrm{m}$. The specific surface area obtained was $1.28 \mathrm{~m}^{2} / \mathrm{g}$ (NT-CS), $1.21 \mathrm{~m}^{2} / \mathrm{g}$ (CA-CS), $1.10 \mathrm{~m}^{2} / \mathrm{g}$ (PU-CS) and 0.70 $\mathrm{m}^{2} / \mathrm{g}$ (cement).

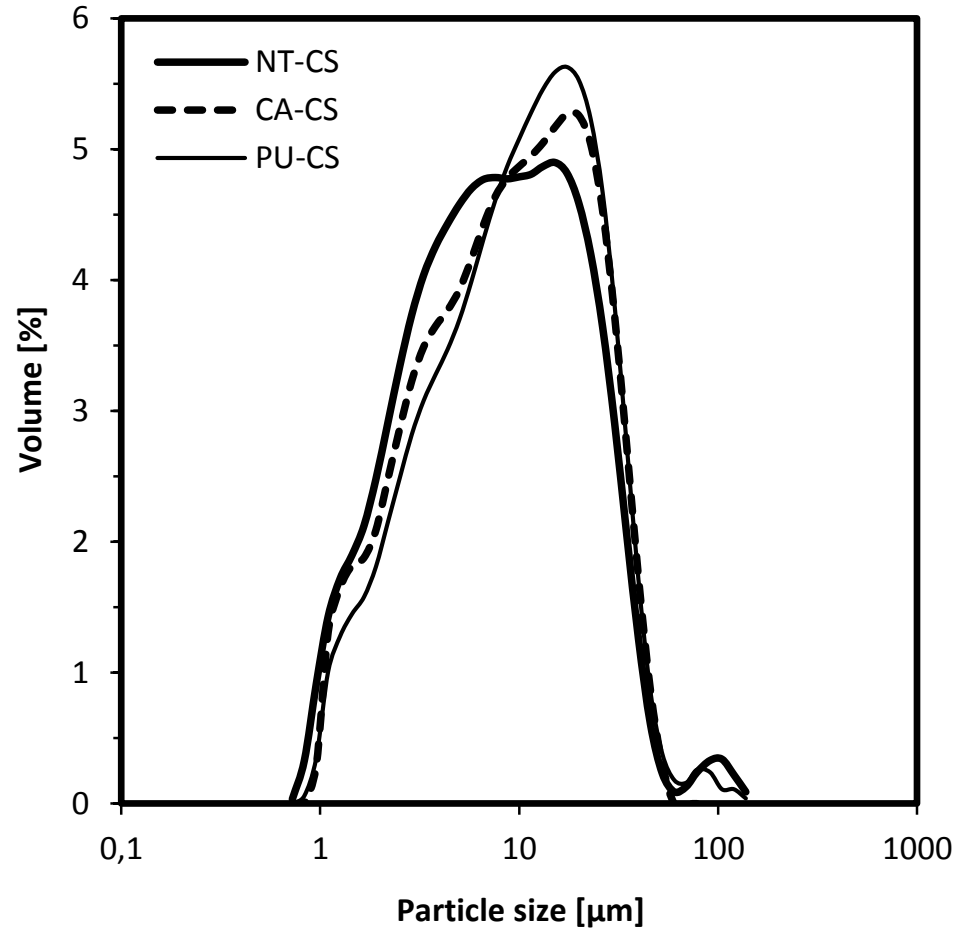

Figure 1: Particle size distribution of NT-CS, CA-CS and PU-CS. 


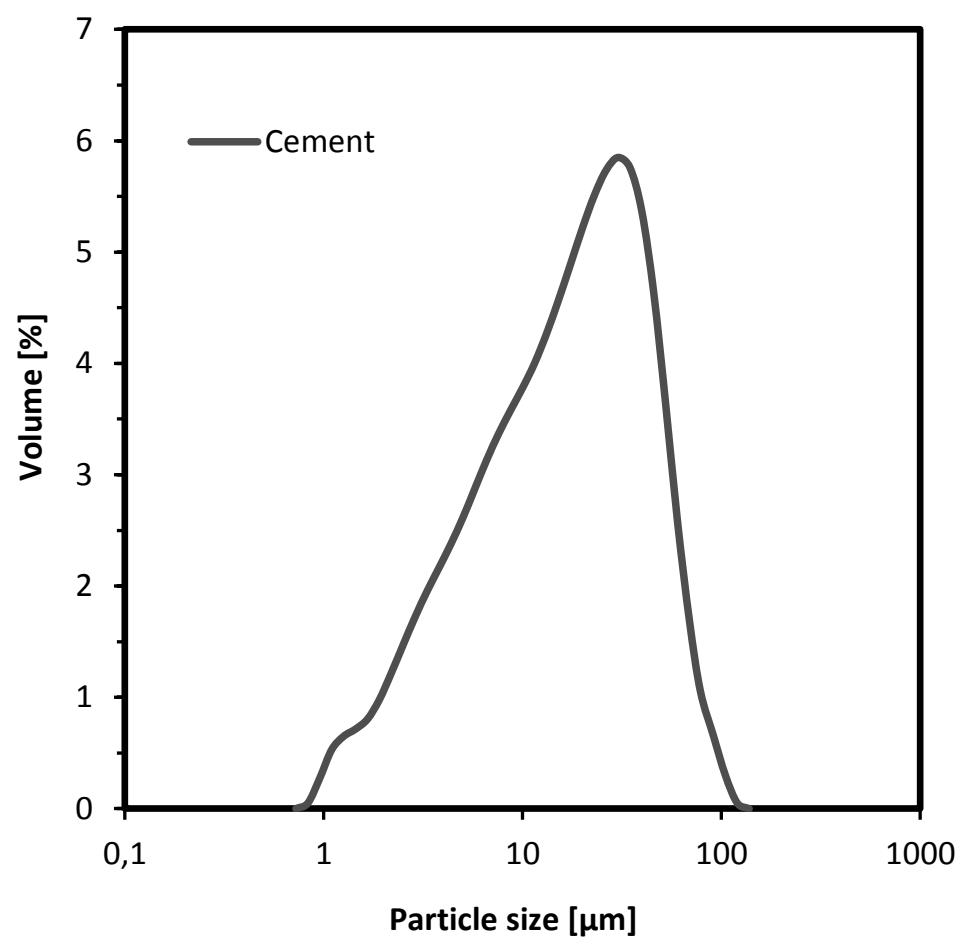

Figure 2: Particle size distribution of HSPC.

Figure 3 shows SEM images of the three CS samples. It can be noticed that the particle size distribution of the three CS samples tends to be homogeneous, showing a maximum particle size of about 30 $\mu \mathrm{m}$; this observation is consistent with the particle size distribution results obtained by using Malvern Mastersizer particle size analyzer.

Regarding morphology, the three studied CS samples show a mix of irregular particles, most of them showing a conchoidal fracture, typical from the copper smelting vitreous slags. Finally, we can observe a mix of rough and smooth particles, CA-CS show the highest surface roughness, in comparison with NT-CS and PU-CS. ROJAS [18] reported that rough surfaces are optimal in terms of lending resistance to concrete prepared with CS, because of the cement paste penetration into the CS cavities, improving adhesion and strength.

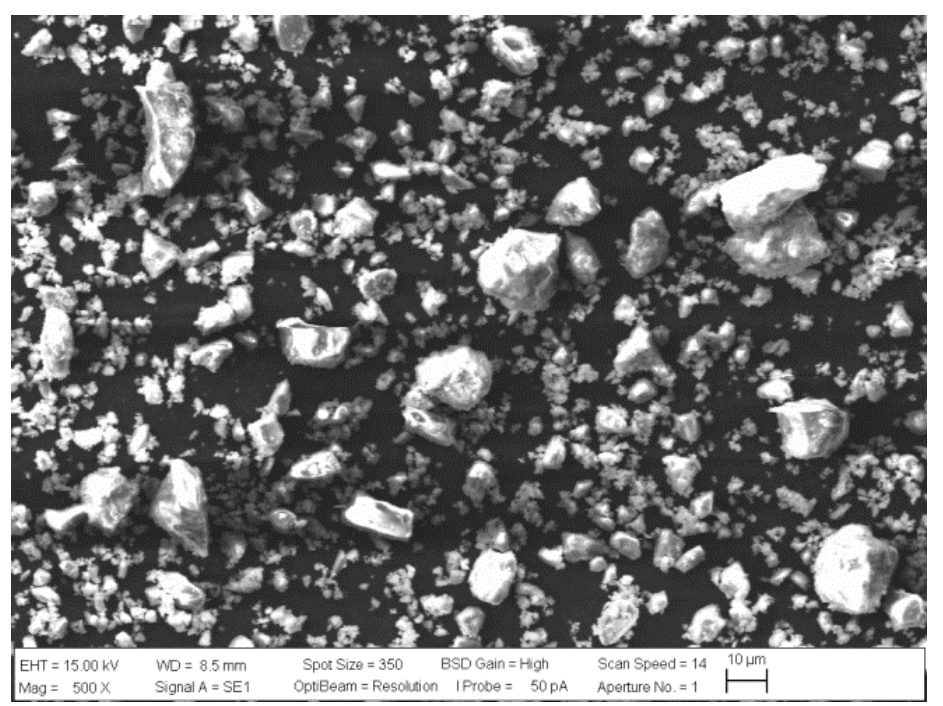

(a) 


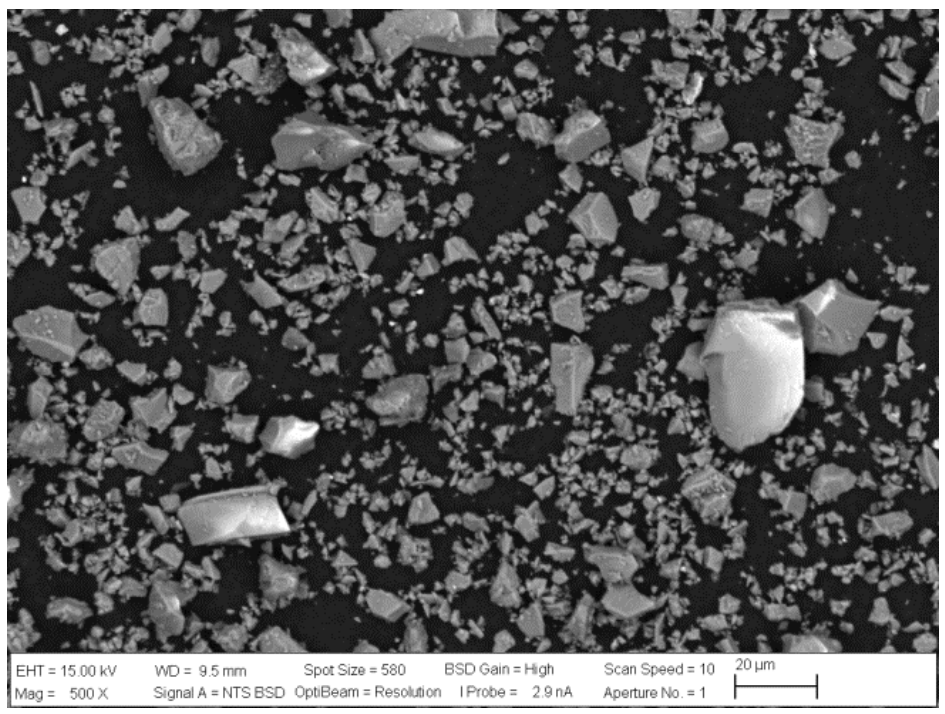

(b)

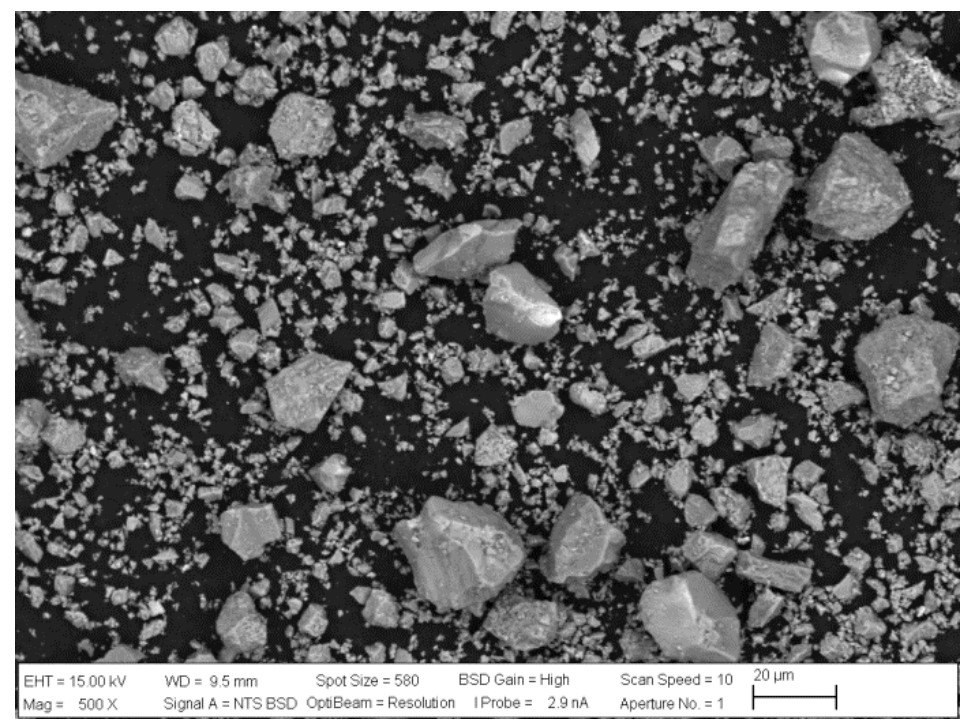

(c)

Figure 3: SEM images of CS NT-CS (a), CA-CS (b) and PU-CS (c).

\subsection{Compressive strength and flexural strength}

Figures 4 to 6 show mortar compressive strength with partial replacement of cement by NT-CS, CA-CS, and PU-CS, and control mortar, respectively. There is a clear increase in compressive strength evident with mortar age. Regarding NT-CS and PU-CS, control mortar shows higher compressive strength values relative to CS substituted mortar at 7 and 28 days, however, at 90 days, values obtained with $5 \%$ substitution are very similar to the control mortar. On the other hand, regarding CA-CS, comparable values between control mortar and 5\% and 10\% CS substituted mortar at both 28 and 90 days are evident; even at 90 days, at 10\% CS substitution a $4 \%$ increase in compressive strength is observed. This fact could be related to the higher roughness of CA-CS, in comparison to NT-CS and PU-CS. In general, tests indicated optimal compressive strength values at $5 \%$ of cement substitution by $\mathrm{CS}$. 


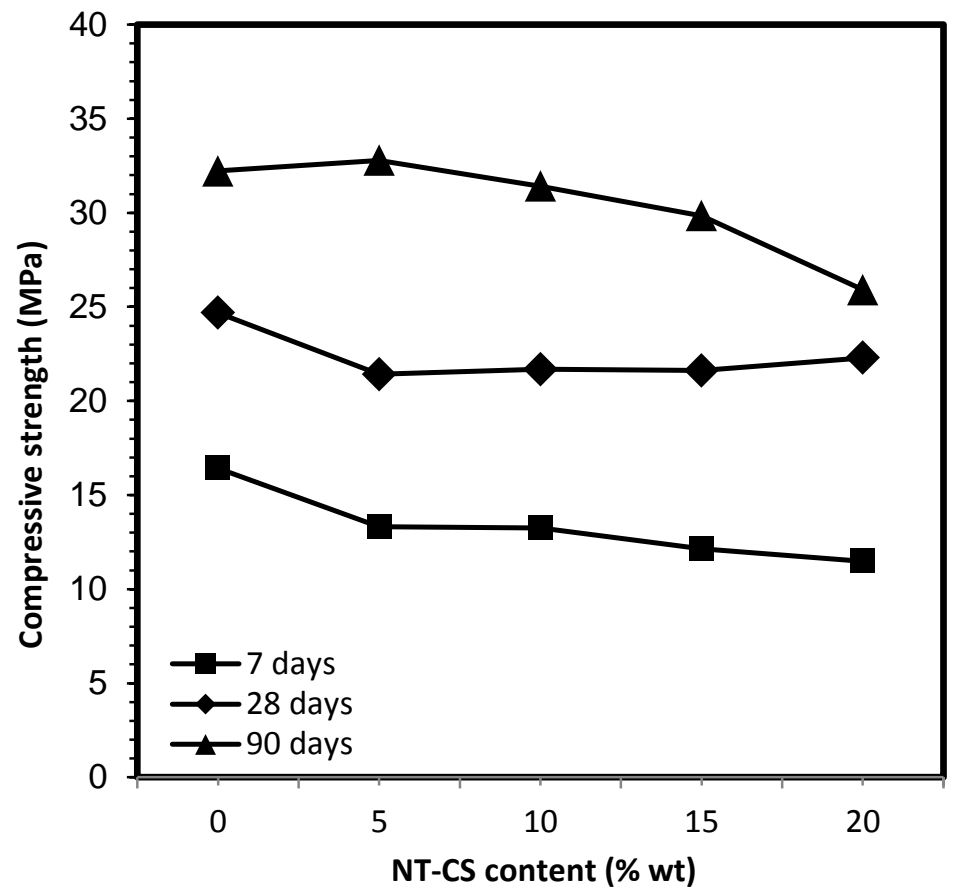

Figure 4: Compressive strength of mortars as a function of NT-CS content at 7, 28 and 90 days.

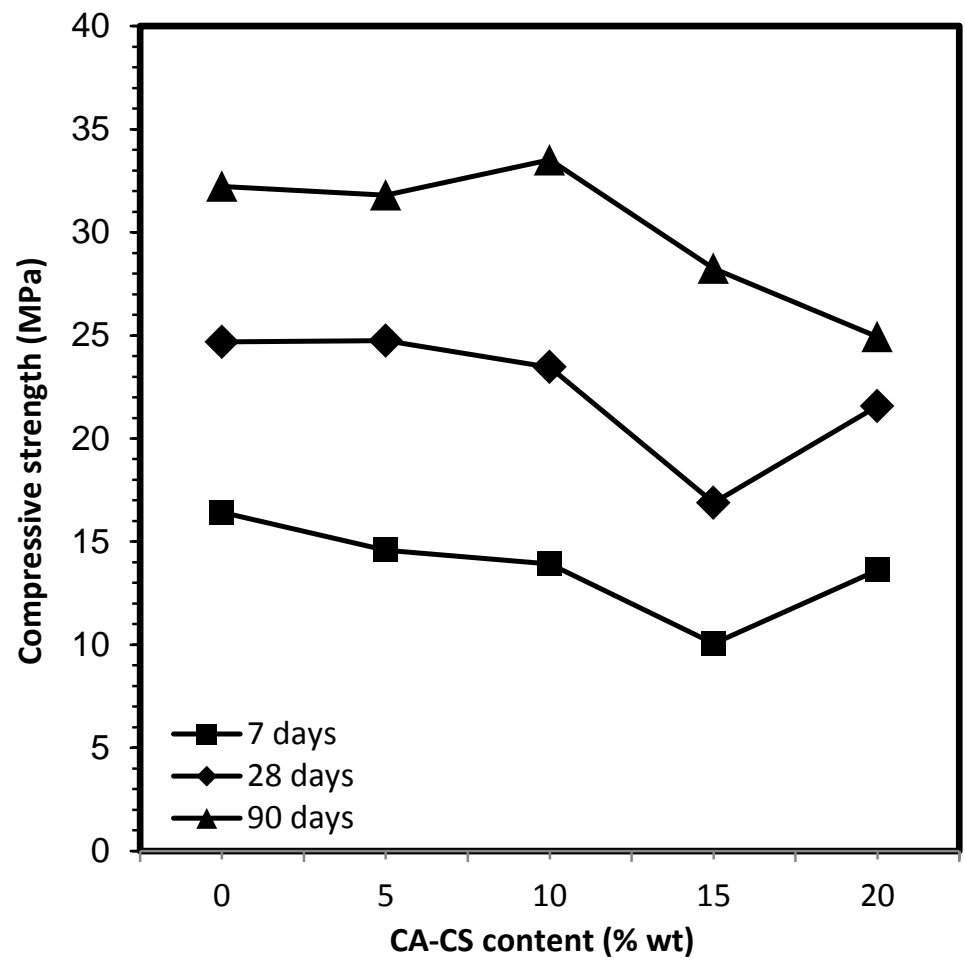

Figure 5: Compressive strength of mortars as a function of CA-CS content at 7,28 and 90 days. 


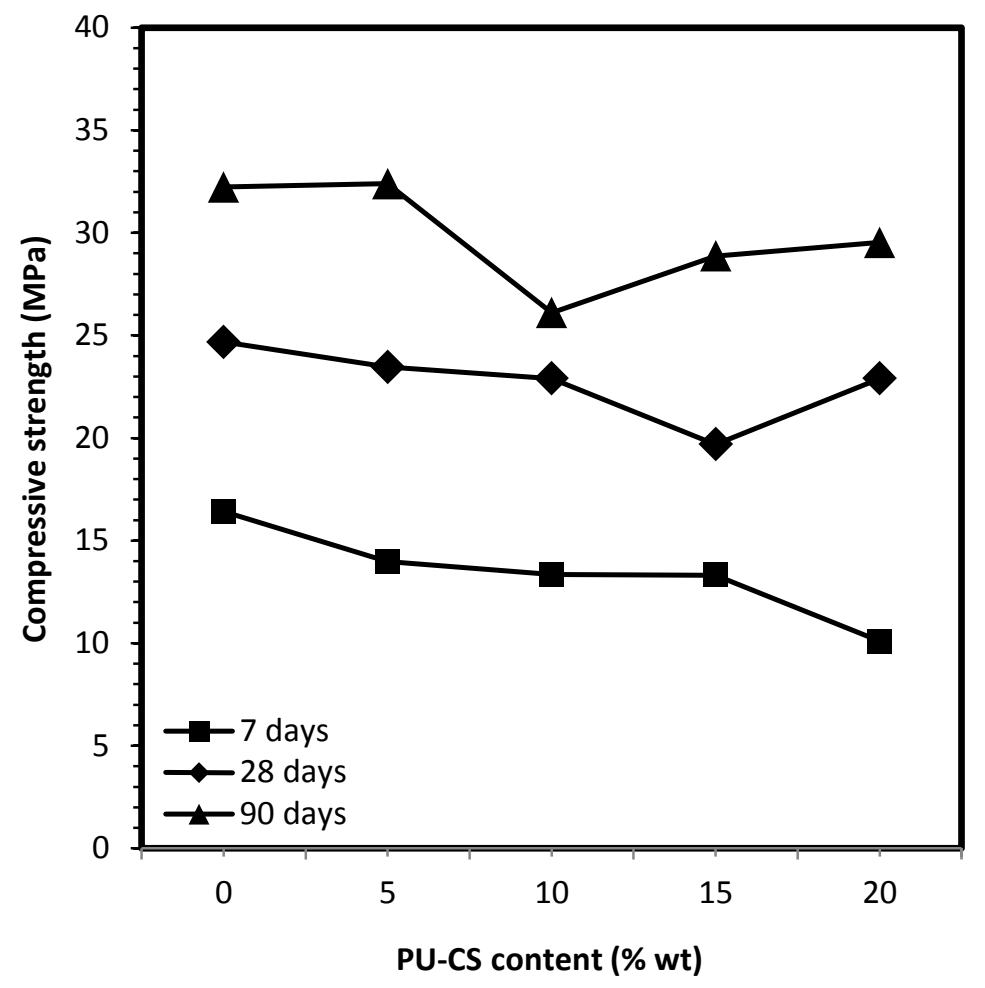

Figure 6: Compressive strength of mortars as a function of PU-CS content at 7, 28 and 90 days.

Figures 7 to 9 show the variation in flexural strength with the partial replacement of cement by NT$\mathrm{CS}, \mathrm{CA}-\mathrm{CS}$, and PU-CS, and control mortar, respectively. There is an evident increase in flexural strength with mortar age, with the highest differences at seven days. At 28 days, $5 \%$ and $10 \%$ cement substitution by NT-CS and CA-CS yielded very similar flexural strength values to control mortar, and even at 5\% substitution by NT-CS, flexural strength was slightly higher; values comparable to those of the control mortar were achieved with substitution by NT-CS at 90 days. Regarding CA-CS, substitutions of 5\% and 15\% resulted in flexural strength values slightly higher than the control mortar. On the other hand, substitution by PU-CS yielded slightly lowered flexural strength values at 90 days. In general, optimal flexural strength values for all CS types evaluated in this study were reached at 90 days, with no noticeable differences between the different CS. 


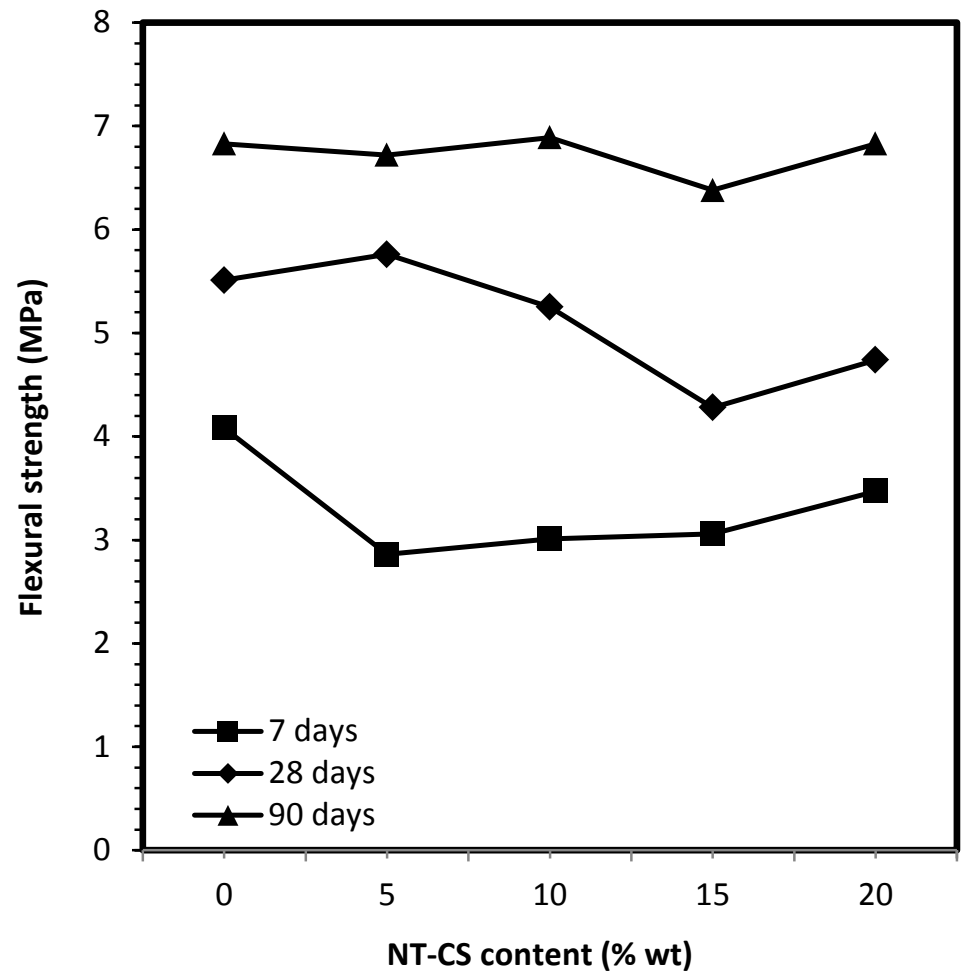

Figure 7: Flexural strength of mortars as a function of NT-CS content at 7, 28 and 90 days.

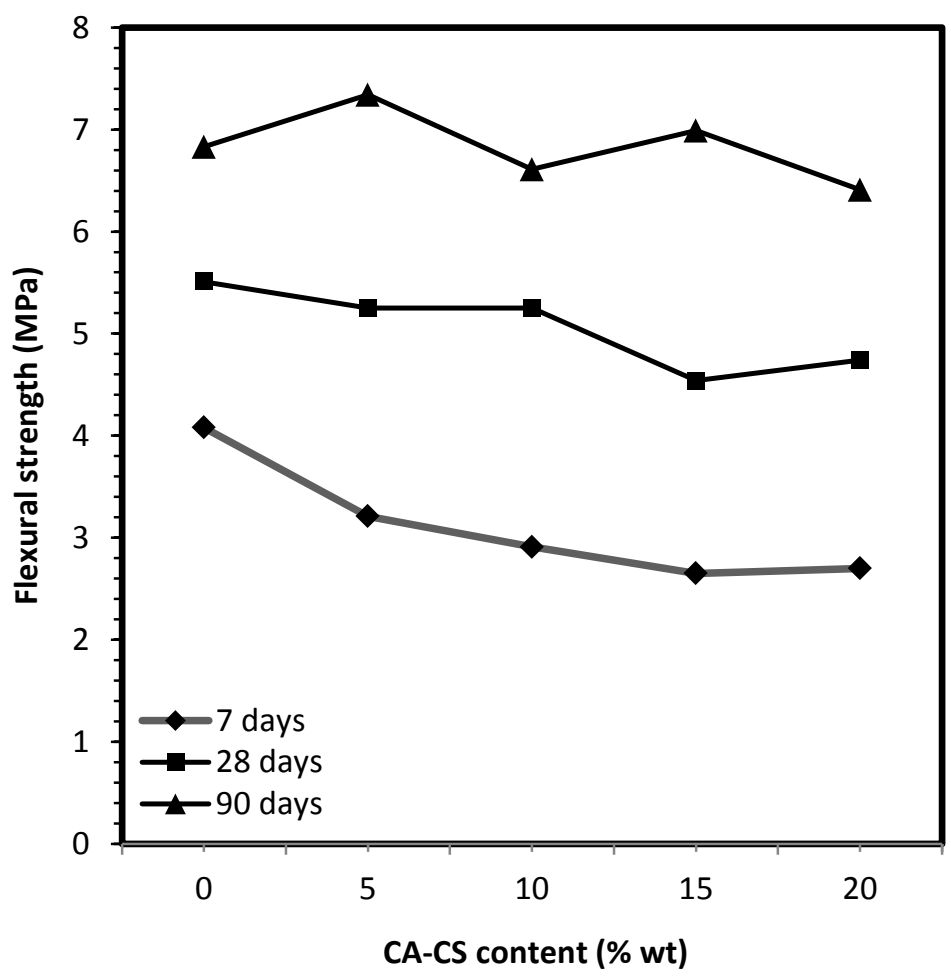

Figure 8: Flexural strength of mortars as a function of CA-CS content at 7, 28 and 90 days. 


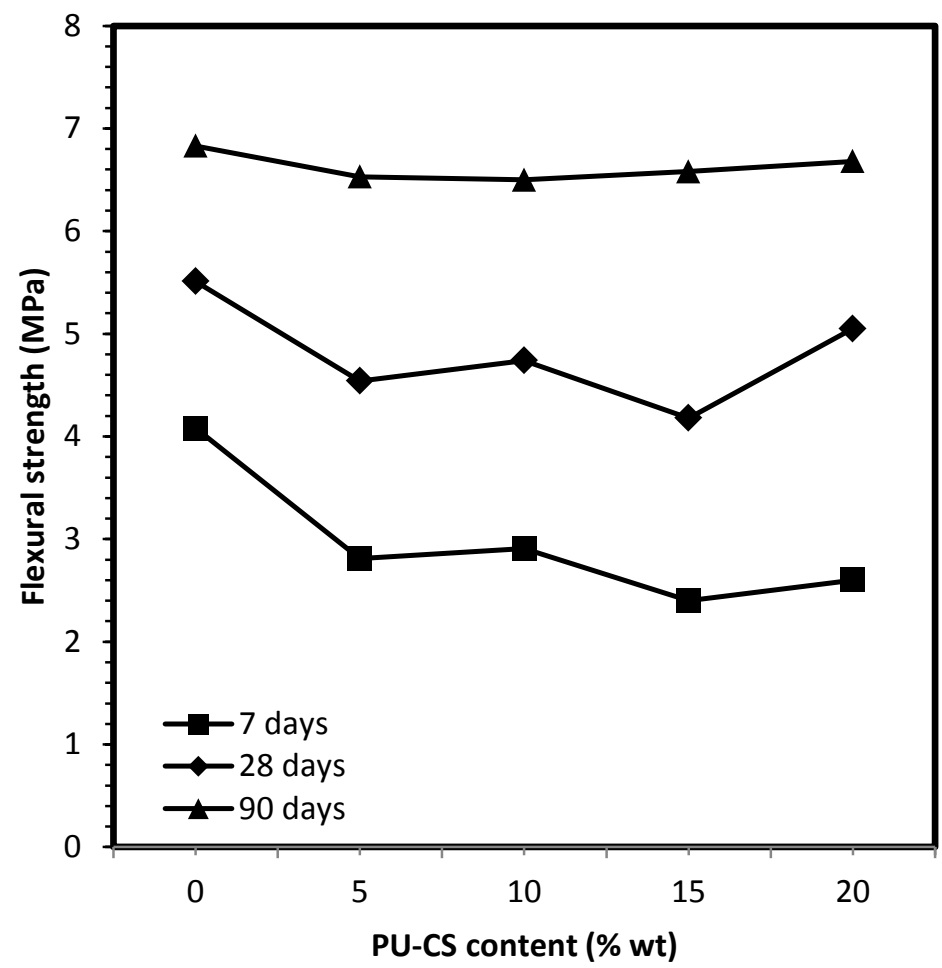

Figure 9: Flexural strength of mortars as a function of PU-CS content at 7, 28 and 90 days.

\section{DISCUSSION}

Results of mechanical tests showed a gradual increase in compressive and flexural strength at 7, 28 and 90 days in mortars comprising CS as partial replacement of cement, as well as in the control mortar.

In general, optimal compressive strength values were achieved at 5\% CS substitution. SINGH et al. [15] indicated that compressive strength decreases with increases in CS content for all curing times assessed, reporting $10 \%$ CS substitution as optimal, beyond $10 \%$ of CS, there is a significant reduction in compressive strength due to the increase in free water content in mixes. ZAIN et al. [7] evaluated CS content ranging from 0 to $10 \%$, testing leachability, compressive strength and hydration in both whole and crushed samples; CS mortar strength was found to be generally lower than the control mortar in their study, with optimum CS content approximately 5\%. ORIZOLA [8] reported a decrease in mortar mechanical strength at 25 and $40 \%$ PC substitution by CS. POOVIZHI AND KATHIRVEL [6] indicated that the optimum percentage of replacement of cement by CS was 15\%. NAIDU et al. [9] reported that the compressive strength of concrete cubes was increased by $18 \%$ with a cement replacement of $15 \%$ by CS for both M25 \& M30, when compared with controlled concrete. ARIÑO et al. [19] indicated that the use of ground CS up to $15 \%$ by mass as a Portland cement replacement increased the strength significantly of cementitious mixes. BRINDHA AND NAGAN [11] reported that the compressive strength of concrete increases with respect to the percentage of CS added by weight of cement up to $15 \%$ of additions. These researchers indicated that for higher replacement of cement by CS (greater than 20\%), compressive strength decreases due to an increase of free water content in the mix.

At 7 and 28 days, control mortar showed higher compressive strength, when compared with mortars comprising a slag component, this difference is more noticeable at seven days. At 90 days, on the other hand, compressive strength values between control and CS mortars are in certain cases more similar. ORIZOLA [8] reported that the development of resistance by the contribution of the CS is a slow process, only becoming noticeable after 60 days.

Flexural strength, in a similar way to compressive strength, was higher in the control mortar at 7 and 28 days, especially at 7 days. At 90 days, however, flexural strength values were comparable for both CS containing and control mortars.

The early declines at seven days in compressive and flexural strength as result of the addition of CS, have also been reported by other researchers (ORIZOLA [8]; ALP et al. [13]; MOBASHER et al. [13]). CS confers a retarding effect on the process (ALP et al. [20]). 
The results obtained with NT-CS, CA-CS and PU-CS as partial replacement of cement showed that $\mathrm{CS}$ yields cementing properties due to the significant amount of calcium as a chemical constituent. ROJAS [18] evaluated the pozzolanic effect of CS in the presence of $\mathrm{Ca}(\mathrm{OH})_{2}$, indicating that it provides resistance to the mixture, and, therefore, the finely divided CS has a cementing value. This researcher used a paste of $95 \%$ CS $(<75 \mu \mathrm{m})+5 \%$ hydrated lime by weight of normal consistency, cured in a humidity chamber up to the test age ( 1 hour, 13 days and 58 days). Using X-ray diffraction, a decrease in the concentration of available portlandite $\left(\mathrm{Ca}(\mathrm{OH})_{2}\right)$ was observed in the lime-slag sample, which was attributed to the formation of hydration products. SINGH et al. [15] studied five different concrete mixes by replacing cement with CS, observing by X-ray diffraction that all mixes consisted of peaks of quartz, portlandite and alite, but that portlandite was the main hydration product during cement hydration. HERNÁNDEZ et al. [21] reported that ground nickel slag as a partial cement substitute did not yield cementing properties, due to the small amount of calcium in its composition.

\section{CONCLUSIONS}

In general, optimal mortar compressive and flexural strength values are achieved at 5\% substitution of cement by CS.

Results of mechanical tests showed a gradual increase in compressive and flexural strength at 7, 28 and 90 days in mortars containing a partial substitution of cement by CS, as well as in the control mortar. At 90 days, compressive and flexural strength values were very similar for both control and experimental mortars.

Differences between control and CS mortars are most evident at seven days. An early decrease in compressive and flexural strength with the addition of CS occurs at seven days and indicates that the presence of CS in the blends confers a retarding effect on the process.

The results obtained with NT-CS, CA-CS, and PU-CS as partial replacement of cement showed that CS provides cementing properties to the mixture due to the significant amount of calcium present in its chemical composition.

These results provide further evidence that slag produced as waste in the copper mining process can viably be used in the construction industry as partial replacement of cement in a mortar, which in turn potentially mitigates adverse effects of copper mining on the environment.

\section{ACKNOWLEDGMENTS}

Osvaldo Pavez gratefully acknowledges the Vice-Rectory of Research and Graduate Studies at the University of Atacama for financial support of Project DIUDA 22299.

\section{BIBLIOGRAPHY}

[1] DEMETRIO, S., AHUMADA, J., DURAN, M.A., et al., "Slag cleaning: The Chilean copper smelter experience", JOM, v. 52, n. 8, pp. 20-25, 2000.

[2] NAZER A., PAYÁ J., BORRACHERO M. V., et al., "Use of ancient copper slags in Portland cement and alkali activated cement matrices", Journal of Environmental Management, v. 167, pp. 115-123, 2016.

[3] GORAI, B., JANA, R.K, PREMCHAND, "Characteristics and utilization of copper slag - A review", Resources Conservation and Recycling, v. 39, pp. 299-313, 2003.

[4] VALENZUELA, A., "Mining waste management in Chile: Experience, challenges and opportunities", In: 14th International EXPOMIN Congress, Santiago, Chile, 25-29 April 2016.

[5] SHI, C., MEYER, C., BEHNOOD, A., "Utilization of copper slag in cement and concrete", Resources Conservation and Recycling, v. 52, pp. 115-1120, 2008.

[6] POOVIZHI, T., KATHIRVEL, P., "Behaviour of concrete with partial replacement of copper slag as cement and fine aggregate", Transactions on Engineering and Sciences, 3, n. 2, pp. 30-35, 2015.

[7] ZAIN, M.F.M., ISLAM, M.N., RADIN, S.S., et al., "Cement-based solidification for the safe disposal of blasted copper slag”, Cement and Concrete Composites, v. 26, n. 7, pp. 845-851, 2004. 
[8] ORIZOLA, S., Uso de escorias de cobre en cementos. Memoria de Ingeniero Civil, Universidad de Chile, Santiago, Chile, 2006.

[9] NAIDU, T., GOVINDA RAJULU, B., RAMLAL, S., "A study on the properties of concrete on partial replacement of cement and sand with copper slag", International Journal of Recent Trends in Engineering \& Research, v. 3, n. 12, pp. 40-50, 2017.

[10] MOURA, W.A., GONÇALVES, J.P., LIMA, M.B.L., "Copper slag waste as a supplementary cementing material to concrete”, Journal of Materials Science, v. 42, n. 7, pp. 2226-2230, 2007.

[11] BRINDHA, D., NAGAN, S., "Durability studies on copper slag admixed concrete", Asian Journal of Civil Engineering (Building and Housing), v. 12, n. 5, pp. 563-578, 2011.

[12] SÁNCHEZ DE ROJAS, M.I., RIVERA, J., FRÍAS, M., et al., "Use of recycled copper slag for blended cements”, Journal of Chemical Technology and Biotechnology, v. 83, n. 3, pp. 209-217, 2008.

[13] ALP, I., DEVECI, H., SÜNGÜN, H., "Utilization of flotation wastes of copper slag as raw material in cement production”, Journal of Hazardous Materials, v. 159, pp. 390-395, 2008.

[14] NAJIMI, M., SOBHANI, J., POURKHORSHIDI, A.R., "Durability of copper slag contained concrete exposed to sulphate attack", Construction and Building Materials, v. 25, n. 4, pp. 1895-1905, 2011.

[15] SINGH, J., SINGH, J., KAUR, M., "Use of copper slag in concrete”, International Journal of Advanced Research in Engineering and Applied Sciences, v. 3, n. 12, pp. 1-10, Dec. 2014.

[16] BHARATH, S., SUBRAJA, S., ARUN KUMAR, P., "Influence of magnetized water on concrete by replacing cement partially with copper slag", Journal of Chemical and Pharmaceutical Sciences, v. 9, n. 4, pp. 2791-2795, 2016.

[17] JUN-WEI, S., "Study on the effect of copper slag admixtures to properties and structure of concrete", Information Technology Journal, v. 12, n. 23, pp. 7396-7400, 2013.

[18] ROJAS, F., Prefactibilidad técnica del uso de la escoria de cobre en morteros y hormigones, Memoria de Ingeniero Civil en Metalurgia, Universidad de Atacama, Copiapó, Chile, 2004.

[19] ARIÑO, A.M., MOBASHER, B., "Effect of ground copper slag on strength and toughness of cementitious mixes”, ACI Materials Journal, v. 96, n. 1, pp. 68-73, 1999.

[20] MOBASHER, B., DEVAGUPTAPU, R., ARINO, A.M., "Effect of copper slag on the hydration of blended cementitious mixtures", In: Proceedings of the ASCE Materials Engineering Conference, pp. 16771686, Washington, Nov. 1996.

[21] HERNÁNDEZ, Y., RINCÓN, O., CAMPOS, W., et al., "Efecto de la escoria de níquel como sustituto parcial del cemento en la durabilidad de morteros expuestos a ambientes marinos", Ciencias Aplicadas, v. 10, pp. 13-19, 2013.

\section{ORCID}

Osvaldo Pavez

Amin Nazer

Macarena Salinas

Bárbara Araya

Oscar Rivera
http://orcid.org/0000-0001-5720-351X

http://orcid.org/0000-0002-0176-2344

http://orcid.org/0000-0002-9617-0578

http://orcid.org/0000-0002-3020-0826

http://orcid.org/0000-0002-6146-9828 